\title{
DINAMIKA TIM AUDIT DAN KUALITAS AUDIT
}

\author{
Yefta Andi Kus Nugroho \\ Fakultas Ekomomi dan Bisnis, Universitas Kristen Satya Wacana
}

(yefta@staff.uksw.edu)

\author{
Dyah Ekasari Sekar Jatiningsih \\ Fakultas Ekonomi dan Bisnis, Universitas Muhammadiyah Yogyakarta \\ (dyah_ekaari@yahoo.com)
}

\begin{abstract}
Audit quality is an important outcome of the work performed by audit team. Works of audit firm generally performed by team and teamwork performance will lead to a good audit quality. Good audit quality, in turn, will result in good audit report. Related to the interaction among audit team members, some factors that need to be highlighted is the structure or composition of the team, communication among team members, and effective use of time. This research intend to explore audit team dynamics in constructing audit quality. The test of audit team dynamics effect on audit quality is performed through a survey research toward auditors who work in audit firms. Result shows that significant aspect of audit team dynamics which affect audit quality are communication and effectiveness of audit time.
\end{abstract}

Keywords: audit quality, audit team, team dynamics, audit communication, audit effectiveness

\section{PENDAHULUAN}

Setiap profesi menekankan perhatian pada kualitas jasa yang diberikan, tidak terkecuali profesi akuntan publik. Kualitas jasa merupakan hal yang penting untuk meyakinkan bahwa profesi telah memenuhi tanggung jawabnya kepada klien, masyarakat umum, serta pemerintah (Boynton et al., 2003: 33). Berdasarkan hal tersebut, maka akuntan publik memiliki kewajiban untuk menjaga kualitas audit yang diupayakan sebagai bentuk perhatian terhadap kualitas. Dengan kualitas audit yang baik akan dihasilkan laporan auditan yang mampu menyajikan temuan dan melaporkan dengan sesungguhnya kondisi keuangan perusahaan sehingga dapat dipercaya sebagai dasar pengambilan keputusan.

De Angelo (1981) mendefinisikan kualitas audit sebagai kemungkinan seorang auditor akan menemukan dan melaporkan salah saji yang material dalam laporan keuangan. Kemungkinan seorang auditor dapat menemukan dan melaporkan salah saji tersebut tergantung pada beberapa faktor, diantaranya adalah tim audit (Hardies et al., 2009). Tim audit merupakan fokus perwujutan kualitas audit yang baik karena teknis proses audit dikendalikan sepenuhnya oleh tim audit. Kelompok kerja (tim) dapat menjadi cara agar organisasi dapat beroperasi secara produktif, meningkatkan fleksibilitas, mengurangi kerusakan hasil kerja, dan meningkatkan kualitas dan kepuasan masyarakat. Manajemen selalu mengkondisikan pekerjaan audit dalam tim untuk mengarahkan pekerjaan audit berfungsi secara efektif (Keen dan Keen,1998). Kualitas audit sebagian besar dibentuk melalui dinamika tim audit. 
Dinamika tim audit dapat dilihat melalui karakteristik dan interaksi antar anggotanya. Karakteristik anggota tim audit yang utama dapat dilihat dari kompetensi dan independensi anggota tim. Kompetensi dan independensi anggota tim merupakan fakta yang harus diperhatikan dalam kaitannya dengan kualitas audit (Chaney et al., 2003). Tim audit biasanya dibentuk dengan mempertimbangkan kompetensi yang diperlukan untuk mencapai tujuan audit. Di samping kompetensi dan independensi, akuntan publik harus terus mengasah profesionalismenya melalui serangkaian pengalaman audit. Menurut Libby dan Trotman (1993), pengalaman yang dimiliki auditor dalam melakukan audit dapat dijadikan pertimbangan auditor berkualitas. Pengalaman memungkinkan auditor memperoleh pengetahuan teknis yang dapat digunakan untuk melakukan penugasan audit. Ho dan May (1993) mengatakan pengalaman akan menghasilkan pengetahuan dan pengetahuan tersebut tersimpan dalam memori auditor. Tubbs (1992) mengungkapan auditor yang berpengalaman memiliki kelebihan dalam hal mendeteksi kesalahan, memahami kesalahan secara akurat dan mencari penyebab kesalahan.

Beberapa hal yang perlu diperhatikan dalam interaksi antar anggota tim adalah struktur atau komposisi tim (Muhammad,2005), komunikasi antar anggota tim (Prasetyo dan Bramantyo, 2007), dan efektivitas penggunaan waktu (Keen dan Keen,1998). Menurut Muhammad (2005), tim audit adalah sebuah kelompok yang dibentuk secara berjenjang dan terdiri dari beberapa individu (senior, supervisor, dan manajer) yang bekerja sama dengan tujuan untuk melaksanakan audit. Komposisi tim audit yang ada tersebut memiliki tugas masing-masing dan diharapkan dapat saling melengkapi sehingga audit yang dilaksanakan berjalan lancar dan berkualitas. Sebelum terhubung dengan klien, auditor harus sudah memiliki mekanisme komunikasi intern yang memadai sehingga tim audit menjadi kompak dan memiliki persepsi serta tujuan yang sama (Prasetyo dan Bramantyo, 2007: 31). Semakin tinggi intensitas komunikasi yang terjadi antara anggota tim audit, semakin banyak hal yang dapat dibagi sehingga tim audit bisa bersama-sama mengungkapkan hal-hal yang menyimpang. Keberhasilan komunikasi internal dalam satu tim audit sangat menunjang kelancaran pelaksanaan audit sehingga kegiatan audit dapat diselesaikan tepat waktu dan tepat kualitas (Prasetyo dan Bramantyo, 2007: 31). Akhirnya mengenai penggunaan waktu audit. Penggunaan waktu audit merupakan faktor penting untuk mlihat sejauh apa kerjasama diantara anggota tim audit terjalin. Keberadaan struktur yang jelas dan komunikasi dengan intensitas yang tinggi akan mengarahkan kerja tim audit menjadi efektif. Efektivitas tercermin dari penggunaan waktu audit oleh tim audit. Berdasarkan beberapa argumen tersebut maka tidaklah salah menempatkan fokus perhatian pembentuk kualitas audit pada dinamika tim audit.

\section{MASALAH DAN PERSOALAN PENELITIAN}

Dinamika tim audit menjadi fokus perhatian dalam mengamati kualitas audit karena tim audit yang menguasai teknis proses pengauditan yang dilakukan. Dinamika tim audit yang baik akan membawa pada penciptaan sinergi yang baik dalam pelaksanaan audit. Tetapi hal yang sebaliknya pula dapat terjadi jika tidak ada sinergi yang baik yang tercipta diantara tim audit. Karakteritik anggota tim (kompetensi, independensi, dan pengalaman) yang tidak memadai akan berdampak pada kerja tim yang tidak efektif. Demikian pula interaksi antar anggota tim. Stuktur atau komposisi tim berperan penting dalam menutup celah kelemahan tim. Tim audit yang memiliki komposisi yang memadai akan mengarahkan kerja tim pada pembagian tugas yang jelas yang pada akhirnya berdampak pada pencapaian tujuan audit. Dalam pelaksanaan tugas audit dibutuhkan kerjasama yang baik antar anggota tim. Kerjasama yang baik tercipta melalui komunikasi yang baik diantara anggota tim. Komunikasi dan struktur atau komposisi yang jelas akan membuat tim dapat menggunakan waktu seefektif mungkin. Berdasarkan hal-hal tersebut maka penelitian ini dilakukan untuk memperoleh gambaran yang jelas mengenai pengaruh karakteristik (kompetensi, independensi, dan pengalaman) anggota 


\section{Yefta Andi Kus Nugroho Dyah Ekasari Sekar Jatiningsih}

tim audit dan interaksi (struktur atau komposisi, komunikasi dan efektivitas penggunaan waktu audit) terhadap kualitas audit.

\section{RERANGKA TEORITIS DAN PENGEMBANGAN HIPOTESIS}

\section{Kualitas Audit}

De Angelo (1981) mendefinisikan kualitas audit sebagai kemungkinan dimana seorang auditor akan menemukan dan melaporkan salah saji yang material dalam laporan keuangan. De Angelo mengembangkan dua dimensi untuk mendefinisikan kualitas audit, yaitu mendeteksi salah saji yang material dan salah saji material tersebut harus dilaporkan (Wooten, 2003: 48). Watkins, Hillison, dan Morecroft (2004) mendefinisikan kualitas audit sebagai kemampuan auditor untuk memastikan bahwa kecurangan tidak terjadi (setidaknya secara material) dan "berani" melaporkan adanya kecurangan tersebut. Pada dasarnya, dua definisi tersebut memiliki kesamaan. Auditor harus dapat mendekteksi adanya salah saji yang material, dan kemudian melaporkan salah saji tersebut agar kualitas audit yang baik dapat tercapai. Jika kualitas auditnya baik, maka akan dihasilkan laporan auditan yang mampu menyajikan temuan dan melaporkan dengan sesungguhnya tentang kondisi keuangan klien sehingga dapat dipercaya sebagai dasar pengambilan keputusan.

\section{Kompetensi Anggota Tim Audit}

Bedard (1986) mengemukakan bahwa kompetensi audit adalah pengetahuan dan ketrampilan prosedural yang luas yang ditunjukkan dalam pengalaman audit (Elfarini, 2007). Dalam standar pengauditan, khususnya standar umum disebutkan bahwa audit harus dilaksanakan oleh seorang atau lebih yang memiliki keahlian dan pelatihan teknis cukup sebagai auditor serta dalam pelaksanaan audit dan penyusunan laporannya auditor wajib menggunakan kemahiran profesionalnya dengan cermat dan seksama. Kompetensi auditor ditunjukkan dengan adanya pengetahuan yang spesifik mengenai sesuatu yang dikerjakan. Bonner 1999 (Nizarul et al., 2007), menunjukkan bahwa pengetahuan spesifik tugas dapat meningkatkan kinerja auditor. Pengetahuan spesifik auditor harus terus diasah melalui keikutsertaan auditor pada kursus-kursus, seminar atau pendidikan berkala.

\section{Independensi Anggota Tim Audit}

Seorang auditor memiliki tanggung jawab kepada klien, masyarakat, kolega dan diri sendiri demi kelanjutan profesi dan jasa yang diberikan (Mautz dan Sharaf, 1961), untuk dapat menjalankan kewajibannya, ada tiga komponen yang harus dimiliki seorang auditor, yaitu kompetensi, independensi dan due professional care. Laporan audit yang berkualitas tergantung pada auditor yang melaksanakan pekerjaannya secara profesional.

Independensi adalah salah satu norma pemeriksaan akuntan yang penting sebab pendapat akuntan independen diberikan untuk tujuan menambah kredibilitas laporan keuangan yang pada dasarnya merupakan gambaran manajemen. Independensi adalah sikap auditor dalam mempertahankan integritas dan objektivitas ketika melaksanakan tugasnya (Noviyanti dan Kusuma, 2001).

\section{Pengalaman Anggota Tim Audit}


Pengalaman audit adalah pengalaman auditor dalam melakukan audit laporan keuangan baik dari segi lamanya waktu maupun banyaknya penugasan yang pernah ditangani (Nurchasanah dan Rahmanti, 1999). Menurut Libby dan Trotman (1993), pengalaman yang dimiliki auditor dalam melakukan audit dapat dijadikan pertimbangan auditor berkualitas. Ketchend dan Strawser (1998) menyatakan bahwa auditor dikatakan memperoleh pengalaman jika auditor telah melakukan audit lebih dari dua tahun. Ho dan May (1993) mengatakan pengalaman akan menghasilkan pengetahuan dan pengetahuan tersebut tersimpan di memori auditor. Tubbs (1992) mengungkapan auditor yang berpengalaman memiliki kelebihan dalam hal mendeteksi kesalahan, memahami kesalahan secara akurat dan mencari penyebab kesalahan.

\section{Komposisi Tim Audit}

Komposisi tim audit merefleksikan penerapan standar umum pertama dari Standar Profesional Akuntan Publik (SPAP): "Audit harus dilaksanakan oleh seorang atau lebih yang memiliki keahlian dan pelatihan teknis yang cukup sebagai auditor" (Farkhani, 2004: 12). Walaupun audit dikatakan dapat dilakukan oleh seorang auditor, tetapi biasanya sebuah tim audit perlu dibentuk dengan mempertimbangkan kompetensi yang dibutuhkan untuk mencapai tujuan audit. Farkhani (2004: 12) mengatakan, setidaknya ada dua faktor yang dapat dijadikan perhatian atau pertimbangan dalam penyusunan komposisi tim audit yaitu (a) latar belakang pendidikan serta pelatihan anggota tim dan (b) masa kerja dan pengalaman anggota tim. Kedua hal ini dapat direfleksikan melalui struktur organisasi yang umum terdapat pada Kantor Akuntan Publik.

Menurut Guy et al. (2002), sebagian besar kantor akuntan mempunyai struktur organisasi serupa yang terdiri atas staf akuntan, akuntan senior, manajer, dan sekutu atau partner atau pemilik. Pada saat seseorang pertama kali bergabung dengan sebuah kantor akuntan publik, mereka pada umumnya diklasifikasikan sebagai staf akuntan atau sering juga disebut asisten atau akuntan junior. Staf akuntan sering melaksanakan tugas audit rutin yang lebih rinci, tetapi karena mereka memiliki pengalaman yang sangat terbatas, maka mereka harus terus dibimbing dari dekat. Akuntan senior bertugas melaksanakan pekerjaan audit lapangan dan biasanya memiliki pengalaman dua sampai lima tahun dalam bidang audit. Akuntan senior melaksanakan penugasan audit di kantor klien dan pada saat bersamaan merencanakan serta mengawasi pekerjaan staf audit dan meninjau kertas kerja, mematuhi batas waktu, dan menjamin bahwa perkembangan pekerjaan audit sesuai dengan target. Manajer dalam suatu kantor akuntan biasanya mempunyai pengalaman paling sedikit lima tahun di kantor akuntan. Manajer membantu akuntan senior merencanakan program audit mereka, meninjau kertas kerja mereka secara periodik, dan memberikan petunjuk lainnya kepada akuntan senior jika dibutuhkan. Sekutu atau pemilik adalah pemilik kantor CPA. Sekutu atau pemilik biasanya sudah mempunyai pengalaman selama sepuluh tahun atau lebih di kantor akuntan. Sekutu atau pemilik memegang seluruh tanggung jawab akhir atas pelaksanaan suatu audit dan karenanya, meninjau pekerjaan audit yang dilakukan staf, akuntan senior, dan manajer serta bertanggung jawab atas pemecahan masalah audit dengan klien, menyetujui bentuk dan isi laporan audit (Guy et al., 2002: 22).

\section{Komunikasi Antara Anggota Tim Audit}

Apabila keterampilan berkomunikasi diterapkan dengan baik, pelaksanaan audit akan berjalan secara efektif dan efisien. Efektif, dalam arti audit dapat mencapai hasil-hasil yang diinginkan. Efisien, karena proses audit dapat dilaksanakan dengan lancar sehingga sumber daya audit benar-benar digunakan untuk mencapai tujuan audit (Prasetyo dan Bramantyo, 2007: 4). Pengertian komunikasi dalam satu kelompok, menurut Ivancevich dan Matteson (1987) adalah 


\section{Yefta Andi Kus Nugroho Dyah Ekasari Sekar Jatiningsih}

pengiriman informasi oleh salah seorang anggota kelompok kepada anggota yang lain dengan menggunakan simbol-simbol tertentu (http://www.akuntansiku.com/). Dalam pelaksanaan audit, supervisor selalu melakukan komunikasi dengan bawahan mengenai instruksi tugas dan tujuan dari tugas yang diberikan kepada bawahan, pemberian saran yang dapat membantu bawahan dalam menjalankan tugasnya (Muhammad, 2005). Oleh karena itu, komunikasi yang terjalin diantara anggota tim audit menjadi aktivitas yang penting karena keberhasilan kerja tim sangat dipengaruhi oleh intensitas komunikasi antara anggota tim audit tersebut.

\section{Efektivitas Penggunaan Waktu Audit}

Kerja sama tim yang baik akan terlihat dalam efektivitas penggunaan waktu. Efektivitas penggunaaan waktu audit adalah penggunaan waktu oleh tim audit yang menunjang pencapaian tujuan audit. Keen dan Keen (1998) menekankan bahwa efektifitas penggunaan waktu audit merupakan faktor penting untuk melihat interaksi antara anggota tim audit.

\section{Pengaruh Kompetensi Anggota Tim Audit Terhadap Kualita Audit}

Kompetensi harus dimiliki oleh seorang auditor. Bonner (1990), menunjukkan bahwa pengetahuan mengenai spesifikasi tugas dapat meningkatkan kinerja auditor berpengalaman, walaupun hanya dalam penetapan risiko analitis (Nizarul et al., 2007). Hal ini menunjukkan bahwa pendapat auditor yang baik akan tergantung pada kompetensi dan prosedur audit yang dilakukan oleh auditor (Hogarth, 1991 dalam Nizarul et al., 2007). Libby dan Frederick (1990) dan Kusharyanti (2003) menemukan bahwa auditor yang lebih berpengalaman mempunyai pemahaman yang lebih baik atas laporan keuangan sehingga keputusan yang diambil bisa lebih baik (Elfarini, 2007). Pertimbangan lain dalam pembuatan keputusan harus dimiliki oleh seorang auditor, dalam pelaksanaan tugas audit tidak mudah menentukan suatu keputusan yang tepat dan terbaik oleh karena itu pertimbangan-pertimbangan lain yang dapat mendukung pengambilan keputusan harus dibuat oleh auditor. Dalam arti lain dapat dikatakan bahwa seorang auditor yang kompeten adalah auditor yang dapat membuat pertimbangan lain dalam pengambilan keputusan sehingga kualitas yang dihasilkan akan baik. Ketika seorang auditor memiliki pengetahuan yang lebih dibandingkan dengan auditor yang lain maka auditor yang berpengetahuan tersebut akan memiliki banyak resensi atau sumber mengenai audit, sehingga dalam memberikan keputusan ia akan memiliki lebih banyak pertimbangan dan akan mempengaruhi kualitas audit semakin tinggi. Oleh karena itu dapat disimpulkan bahwa semakin berkompeten seorang auditor maka kualitas audit yang dihasilkan juga akan semakin tinggi. Berdasarkan argumen tersebut dikemukakan hipotesis sebagai berikut.

\section{$\mathrm{H1}$ : Kompetensi auditor berpengaruh terhadap kualitas audit}

\section{Pengaruh Independensi Anggota Tim Audit Terhadap Kualitas Audit}

Independensi adalah salah satu sikap yang harus dimiliki oleh seorang auditor. Tanpa sikap independen, auditor tidak dapat memperoleh hasil audit yang berkualitas. Independensi tercermin ketika seorang auditor dalam melaksanakan tugas auditnya, tidak bersikap subjektif atau memihak kepada salah satu pihak, selain itu ketika auditor tidak berkerja pada perusahaan yang memiliki hubungan khusus dengannya sebagai contoh adalah auditor tidak mengaudit perusahaan yang ada hubungan keluarga dengannya. Jika akuntan tidak independen terhadap kliennya, maka opininya tidak akan memberikan tambahan apapun (Mautz dan Sharaf, 1961:246). Kode Etik Akuntan publik (Nizarul et al., 2007) menjelaskan bahwa independensi merupakan sikap yang diharapkan dari seorang akuntan publik untuk tidak 
mempunyai kepentingan pribadi dalam pelaksanaan tugasnya, yang bertentangan dengan prinsip integritas dan obyektivitas. Jika auditor melakukan tugas audit pada perusahaan yang memiliki hubungan keluarga, maka akan banyak kemungkinan yang terjadi antara lain keinginan untuk membantu perusahaan agar tidak terlihat buruk oleh calon investor, perasaan sungkan kepada saudara yang berada di perusahaan klien, dan banyak pertentangan batiniah yang harus dihadapi oleh auditor ketika melaksanakan tugas auditnya. Apabila halhal tersebut terjadi maka independensi dari auditor akan menjadi rendah, karena auditor akan mulai berfikir untuk melakukan hal-hal yang kurang baik disebabkan oleh tekanan-tekanan yang ada dan munculnyya sifat subjektifitas. Berdasarkan argumen tersebut dikemukakan hipotesis sebagai berikut.

H2: Independensi auditor berpengaruh terhadap kualitas audit

\section{Pengaruh Pengalaman Tim Audit Terhadap Kualitas Audit}

Pendapat mengenai auditor yang berpengalaman berbeda-beda menurut banyak orang. Pengalaman merupakan guru terbaik. Akuntan publik yang sudah berpengalaman akan mampu mengidentifikasi secara lebih baik mengenai kesalahan-kesalahan dan kecurangankecurangan yang terjadi. Biasanya seseorang yang berpengalaman mampu menyelesaikan permasalahan dengan cepat, demikian pula seorang auditor. Auditor yang sudah berpengalaman, ketika melakukan audit, sudah mengetahui hal-hal apa saja yang akan dilakukan untuk menyelesaikan pekerjaanya. Sehingga dapat disimpulkan bahwa pengalaman auditor dapat menentukan kualitas audit melalui pengetahuan dan keunggulankeunggulan yang diperolehnya dari pengalaman melakukan audit. Semakin berpengalaman seorang auditor, maka hasil pekerjaan yang diberikan akan semakin bagus dan berkualitas. Hal ini dapat menambah kualitas audit.

Menurut Ketchend dan Strawser (1998), pengalaman auditor (lebih dari dua tahun) dapat menentukan kualitas audit melalui pengetahuan yang diperolehnya dari pengalaman melakukan audit. Pengalaman akan menghasilkan pengetahuan dan pengetahuan tersebut tersimpan dalam memori auditor Ho dan May (1993). Memori auditor memegang peranan penting dalam kualitas pertimbangannya (Johnson 1994). Meidawati (2001) pengalaman merupakan atribut yang penting dimilki oleh auditor, hal ini terbukti dengan tingkat kesalahan yang dibuat oleh auditor yang tidak berpengalaman lebih banyak daripada auditor yang berpengalaman Widagdo el al. (2002). Ishak (2000) dalam penelitiannya mengemukakan bahwa pengalaman melakukakn audit berpengaruh secara signifikan terhadap kualitas audit. Berdasarkan argumen diatas, maka dikemukakan hipotesis sebagai berikut.

$\mathrm{H}_{3}$ : Pengalaman melakukan audit berpengaruh terhadap kualitas audit.

\section{Pengaruh Komposisi Tim Audit terhadap Kualitas Audit}

Audit pada umumnya tidak dilakukan hanya oleh seorang auditor. Tim audit biasanya dibentuk dengan mempertimbangkan kompetensi yang diperlukan untuk mencapai tujuan audit (www.kp2ma.uajy.ac.id). Struktur tim audit mengacu pada tingkatan dimana setiap anggotanya mempunyai beban aktivitas yang terbatas dan perilaku yang berbeda. Tujuan diberikannya batasan beban tugas tersebut adalah untuk memastikan kesesuaian tingkat koordinasi dan integrasi kegiatan tim audit untuk mencapai tujuan kegiatan audit (Muhammad, 2005: 127). Francis dalam Hardies et al. (2009) menyatakan bahwa karakteristik tim audit seperti komposisi tim audit merupakan faktor yang berpengaruh terhadap kualitas audit. Apabila 


\section{Yefta Andi Kus Nugroho Dyah Ekasari Sekar Jatiningsih}

komposisi staf akuntan, akuntan senior, manajer, dan rekan dalam suatu tim audit telah sesuai dengan kebutuhan, maka pelaksanaan audit tidak akan terhambat sehingga kualitas audit akan terjaga.

\section{$\mathrm{H}_{4}$ : Komposisi tim audit berpengaruh terhadap kualitas audit}

\section{Pengaruh Komunikasi Antara Anggota Tim Audit terhadap Kualitas Audit}

Tim audit adalah sebuah tim yang dibentuk secara berjenjang dan terdiri dari beberapa individu yang bekerja sama dengan tujuan untuk melaksanakan audit (Muhammad, 2005). Karena terdiri dari beberapa individu, maka komunikasi antar anggota tim audit merupakan aktivitas dasar untuk menggabungkan berbagai informasi dari setiap anggota menjadi sebuah kesatuan yang bermanfaat untuk pelaksanaan audit. Sejak proses awal perencanaan audit hingga pelaporan hasil audit akhir, komunikasi pasti diperlukan sebagai media untuk berbagi informasi maupun dalam melakukan koordinasi antar anggota tim audit. Dengan komunikasi intern yang memadai, maka tim audit menjadi kompak dan memiliki persepsi serta tujuan yang sama. Sebagaimana diungkapkan Prasetyo dan Bramantyo (2007) bahwa keberhasilan komunikasi internal dalam satu tim audit sangat menunjang kelancaran pelaksanaan audit sehingga kegiatan audit dapat diselesaikan tepat waktu dan tepat kualitas.

\section{$\mathrm{H}_{5}$ : Komunikasi antara anggota tim audit berpengaruh terhadap kualitas audit}

\section{Pengaruh Efektivitas Penggunaan Waktu Audit Terhadap Kualitas Audit}

Tim audit bekerja dengan batasan waktu tertentu. Keterbatasan waktu harus disikapi dengan tepat agar tujuan audit dapat tercapai. Koordinasi dan komunikasi diantara anggota tim audit akan menyebabkan tim audit dapat bekerja dengan efektif. Keen dan Keen (1998) menyatakan bahwa pemanfaatan waktu yang efektif menunjukkan semangat seluruh anggota tim untuk mencapai tujuan audit yang telah ditetapkan. Semangat dan keinginan untuk mencapai tujuan dan menyelesaikan penugasan audit yang ditunjukkan dengan pemanfaatan waktu yang efektif akan menyebabkan perwujudan kualitas audit yang memadai. Berdasarkan argument tersebut dikemukakan hipotesis sebagai berikut.

$\mathrm{H}_{6}$ : Efektivitas penggunaan waktu audit berpengaruh terhadap kualitas audit

\section{Metoda Penelitian}

Penelitian ini menggunakan data primer, yaitu data yang berasal dari sumber asli (Priadana, 2009: 36). Data primer diperoleh dari penyebaran kuesioner kepada responden yang meliputi auditor yang bekerja pada Kantor Akuntan Publik di Pulau Jawa.

Adapun populasi dalam penelitian ini adalah auditor yang bekerja di Kantor Akuntan Publik di Pulau Jawa. Penelitian dilakukan dengan meneliti sebagian dari elemen-elemen populasi atau disebut dengan penelitian sampel (Priadana, 2009: 103). Teknik sampling yang digunakan untuk penelitian ini adalah judgement sampling sebagai bagian dari purposive sampling. Judgement atau purposive yakni penarikan sampel yang dilakukan karena tujuan penelitian hanya dimaksudkan untuk mengungkap variabel sebatas dalam sampel itu saja (Priadana, 2009: 167). Responden yang dipilih adalah yang memiliki karakteristik khusus dan dalam posisi dapat memberikan informasi yang dikehendaki. Sampel ditentukan secara tidak acak dengan didasarkan pada kriteria tertentu meliputi auditor yang bekerja sebagai auditor junior, auditor senior, manajer, dan pemilik pada Kantor Akuntan Publik. 
Metode pengumpulan data dilakukan secara langsung. Yaitu dengan mendatangi Kantor Akuntan Publik di Pulau Jawa dan melakukan penyebaran kuesioner kepada auditor untuk memperoleh data yang diperlukan dalam penelitian ini.

\section{Pengukuran Variabel \\ Kompetensi Anggota Tim Audit $\left(X_{1}\right)$}

Kompetensi meliputi banyak hal salah satunya adalah pengambilan keputusan, jika seseorang memiliki kompetensi yang tinggi maka kemungkinan setiap keputusan yang ia ambil akan berkualitas. Kompetensi anggota tim audit terbentuk seiring dengan keikutsertaan anggota tim audit pada kursus-kursus atau pendidikan berkala. Sehubungan dengan itu kompetensi anggota tim audit akan diukur dengan jumlah keikutsertaan pada kursus atau pendidikan berkala yang relevan dengan bidang audit.

\section{Independensi Anggota Tim Audit ( $\left.\mathrm{X}_{2}\right)$}

Independensi merupakan sikap yang tidak memihak kepada salah satu pihak saja atau bersikap objektif dalam melaksanakan tugas auditnya, selain itu auditor juga harus melakukan audit pada entitas yang tidak yang tidak memiliki hubungan dengannya (Arens, 2004). Independensi akan diukur dengan beberapa pertanyaan tentang sikap independen auditor dan pendapat jika diperhadapkan dengan tugas audit pihak yang memiliki hubungan istimewa.

\section{Pengalaman Melakukan Audit $\left(\mathrm{X}_{3}\right)$}

Pengalaman anggota tim audit melakukan audit dapat dilihat dari lama bekerja sebagai auditor dan jumlah penugasan audit yang pernah dilkakukan. Variabel pengalaman dalam penelitian ini akan diukur dengan menggunakan pertanyaan tentang lama bekerja sebagai auditor dan jumlah penugasan audit yang pernah dilakukan.

\section{Komposisi Tim Audit $\left(\mathrm{X}_{4}\right)$}

Komposisi tim audit yang dimaksud dalam penelitian ini adalah proporsi dari jumlah staf akuntan, akuntan senior, manajer, dan partner sebuah tim audit pada suatu kegiatan audit. Instrumen yang digunakan untuk mengukur komposisi tim audit berkaitan dengan proporsi dalam tim audit yang dihubungkan dengan kualitas audit yang dihasilkan meliputi : (1) jumlah staf akuntan lebih banyak daripada komposisi tim yang lain, (2) jumlah akuntan senior lebih banyak daripada komposisi tim yang lain, (3) jumlah manajer lebih banyak daripada komposisi tim yang lain, (4) jumlah pemilik atau partner lebih banyak daripada komposisi tim yang lain.

\section{Komunikasi Antara Anggota Tim Audit ( $\left.\mathrm{X}_{5}\right)$}

Komunikasi antara anggota tim merupakan aktivitas dasar dalam rangka menggabungkan berbagai informasi menjadi produk akhir berupa opini audit (Muhammad, 2005). Indikator empirik yang digunakan untuk mengukur adalah variable-variabel komunikasi yang digunakan Rudolph dan Welker (1998) meliputi : (1) kelebihan informasi, (2) boundary spanning, (3) kepuasan atas pengawasan, (4) keakuratan informasi (Muhammad, 2005: 128).

\section{Efektifitas Penggunaan Waktu Audit ( $\left.\mathrm{X}_{6}\right)$}

Efektivitas penggunaan waktu audit menunjukkan kepuasan akan pengalaman tim audit, kinerja tim audit, dan semangat tim (Keen dan Keen, 1998). Berdasarkan pendapat tersebut efektifitas penggunaan waktu audit diukur dengan mengajukan tiga pertanyaan tertang persepsi anggota tim tentang waktu, jumlah waktu yang digunakan dalam suatu penugasan audit, dan selisih waktu yang direncanakan dengan waktu yang sesungguhnya digunakan.

Kualitas Audit ( $Y$ ) 
Yefta Andi Kus Nugroho

Dyah Ekasari Sekar Jatiningsih

Kualitas audit adalah kemungkinan dimana seorang auditor akan menemukan dan melaporkan salah saji yang material dalam laporan keuangan (Hardies et al., 2009). Indikator empirik yang digunakan adalah indikator kualitas audit yang dikemukakan oleh Harhinto (2004) dan Kartika Widhi (2006) yaitu sebagai berikut : (a) melaporkan semua kesalahan klien, (b) pemahaman terhadap sistem informasi akuntansi klien, (c) komitmen yang kuat dalam menyelesaikan audit, (d) berpedoman pada prinsip auditing dan prinsip akuntansi dalam melakukan pekerjaan lapangan, (e) tidak percaya begitu saja terhadap pernyataan klien, (f) sikap hati-hati dalam pengambilan keputusan (Elfarini, 2007: 49).

\section{MODEL PENELITIAN}

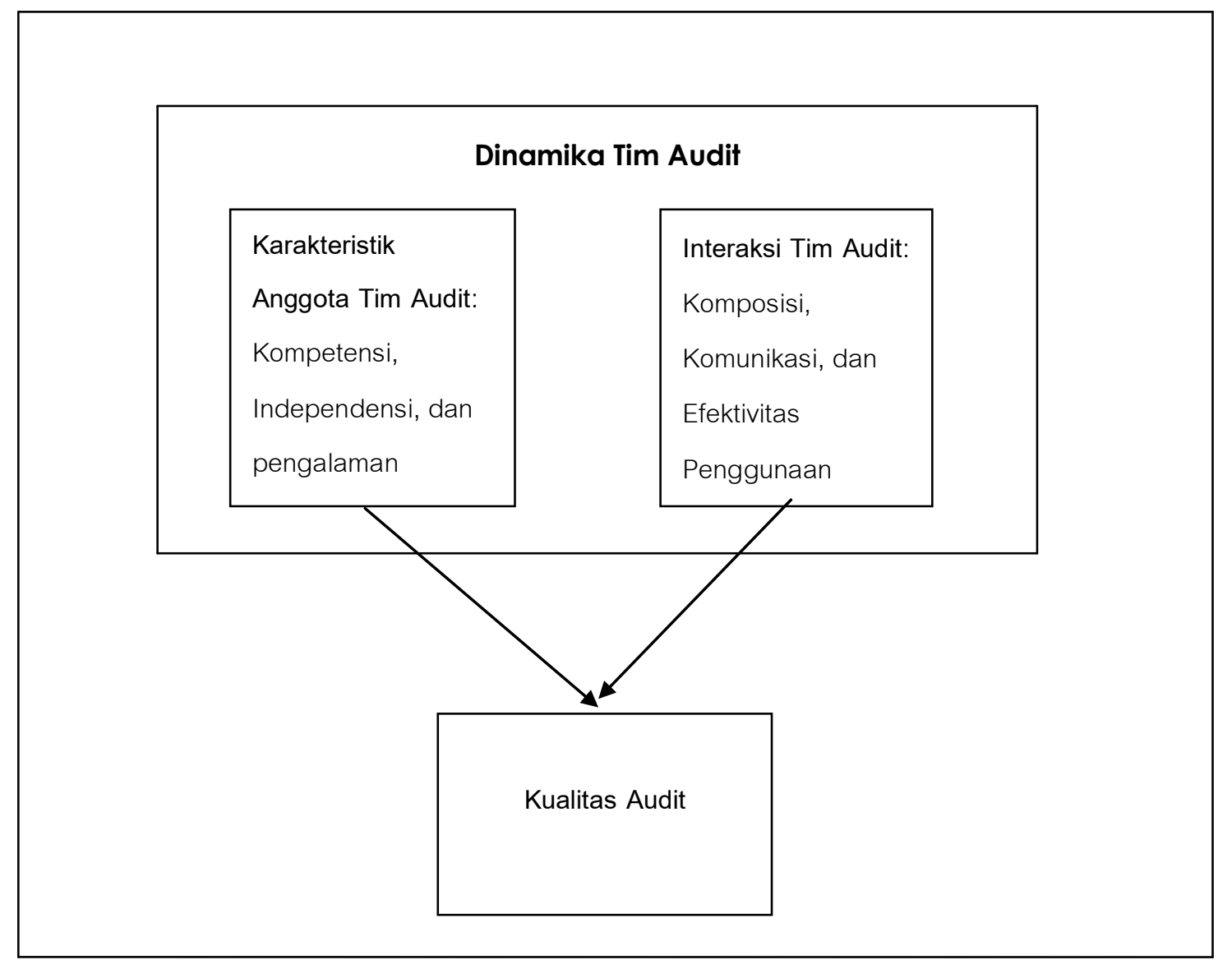

\section{HASIL PENELITIAN}

Penelitian ini dilakukan dengan menyebarkan kuesioner pada para akuntan yang bekerja di beberapa Kantor Akuntan Publik di Jakarta, Semarang, Yogyakarta, dan Surabaya. Penyebaran kuesioner yang dilakukan berhasil menemukan 29 Kantor Akuntan Publik yang bersedia untuk berpartisipasi sebagai responden dalam penelitian ini. Sebaran kedua puluh sembilan KAP tersebut adalah 5 KAP berlokasi di Yogyakarta, 2 KAP berlokasi di Surakarta, 12 KAP berlokasi di Jakarta, 8 KAP di Semarang, dan 2 KAP di Surabaya. Selengkapnya hasil penyebaran kuesioner dapat dilihat pada tabel berikut ini. 
Tabel 1

Rincian Perolehan Data Dinamika Tim Audit

\begin{tabular}{|l|c|c|}
\hline Keterangan & Jumlah & Prosentase \\
\hline Kuesioner yang disebar & 256 & $100 \%$ \\
\hline Kuesioner yang tidak kembali & 127 & $49,6 \%$ \\
\hline Kuesioner yang kembali & 129 & $50,4 \%$ \\
\hline Kuesioner yang cacat/tidak lengkap & 55 & $21,48 \%$ \\
\hline Kuesioner layak olah & 74 & $28,9 \%$ \\
\hline
\end{tabular}

Tabel 2

Karakteristik Responden

\begin{tabular}{|l|l|l|l|}
\hline Keterangan & Kategori & Frekuensi & Prosentase \\
\hline \multirow{3}{*}{ Jenis Kelamin } & Pria & 48 & 64,9 \\
\cline { 2 - 4 } & Wanita & 26 & 35,1 \\
\hline \multirow{5}{*}{ Jabatan } & D3 & 5 & 6,8 \\
\cline { 2 - 4 } & S1 & 68 & 91,9 \\
\cline { 2 - 4 } & S2 & 1 & 1,4 \\
\cline { 2 - 4 } & Staf Auditor & 46 & 62,2 \\
\cline { 2 - 4 } & Senior Auditor & 26 & 35,1 \\
\cline { 2 - 4 } & Manajer & 2 & 2,7 \\
\hline
\end{tabular}

Adapun statistik deskriptif data penelitian yang terkumpul dirangkum sebagai berikut.

Tabel 3

Statistik Deskriptif

\begin{tabular}{|l|l|l|l|}
\hline Variabel & Minimum & Maksimum & Rata-rata \\
\hline Umur & 20 & 61 & 28,65 \\
\hline Kualitas Audit & 18 & 30 & 25,01 \\
\hline Kompetensi & 8 & 25 & 19,30 \\
\hline Independensi & 11 & 24 & 17,95 \\
\hline Komunikasi & 7 & 25 & 18,11 \\
\hline Efektivitas & 0,43 & 2,50 & 1,18 \\
\hline Pengalaman & 0,80 & 35 & 3,8 \\
\hline
\end{tabular}

Penelitian ini menggunakan kuesioner untuk memperoleh data, sehingga perlu dilakukan pengujian kualitas data menggunakan uji validitas dan reliabilitas. Esensi dari validitas adalah akurasi, dan reliabilitas adalah konsistensi. Validitas data penelitian ditentukan oleh proses pengukuran yang akurat. Suatu instrumen pengukuran dikatakan valid jika instrumen tersebut mengukur apa yang seharusnya diukur (Priadana, 2009: 112). Pengujian validitas dilakukan dengan menggunakan program statistik SPSS 12.0 dengan melihat korelasi untuk masing-masing item. Syarat minimum yang harus dipenuhi agar angket dapat dikatakan valid adalah apabila $r$ hasil positif dan lebih besar dari $r$ tabel. Suatu data penelitian yang valid, bagaimana pun harus reliable karena akurasi memerlukan konsistensi. Konsep reliabilitas adalah konsistensi di antara butir-butir pertanyaan atau pertanyaan dalam suatu instrumen. Tingkat keterkaitan antara butir 
pertanyaan atau pertanyaan dalam suatu instrumen untuk mengukur construct tertentu menunjukkan tingkat reliabilitas konsistensi internal instrumen yang bersangkutan (Priadana, 2009: 112). Uji reliabilitas dihitung dengan menggunakan rumus Cronbach's Alpha. Jika nilai koefisien alpha lebih besar dari 0,60 maka disimpulkan bahwa isntrumen penelitian tersebut handal atau reliabel (Elfarini, 2007: 61).

Berdasarkan karakteristik variabel yang diuji maka berikut adalah hasil uji validitas dan reliabilitas variabel kualitas audit, kompetensi, komunikasi, dan independensi.

Tabel 4

Uji Validitas Kualitas Audit

\begin{tabular}{|l|l|l|l|}
\hline Indikator & Pearson Corelation & Kriteria & Simpulan \\
\hline $\mathrm{Ka} 1$ & 0,688 & 0,400 & valid \\
\hline $\mathrm{Ka} 2$ & 0,672 & 0,400 & valid \\
\hline $\mathrm{Ka} 3$ & 0,705 & 0,400 & valid \\
\hline $\mathrm{Ka} 4$ & 0,742 & 0,400 & valid \\
\hline $\mathrm{Ka} 5$ & 0,745 & 0,400 & valid \\
\hline $\mathrm{Ka} 6$ & 0,571 & 0,400 & valid \\
\hline
\end{tabular}

Tabel 5

Uji Validitas Kompetensi Auditor

\begin{tabular}{|l|l|l|l|}
\hline Indikator & Pearson Corelation & Kriteria & Simpulan \\
\hline $\mathrm{Km} 1$ & 0,714 & 0,400 & valid \\
\hline $\mathrm{Km} 2$ & 0,704 & 0,400 & valid \\
\hline $\mathrm{Km} 3$ & 0,560 & 0,400 & valid \\
\hline $\mathrm{Km} 4$ & 0,536 & 0,400 & valid \\
\hline $\mathrm{Km} 5$ & 0,621 & 0,400 & valid \\
\hline
\end{tabular}

Tabel 6

Uji Validitas Komunikasi Tim Audit

\begin{tabular}{|l|l|l|l|}
\hline Indikator & Pearson Corelation & Kriteria & Simpulan \\
\hline $\mathrm{Kmsl} 1$ & 0,533 & 0,400 & valid \\
\hline $\mathrm{Kmsl} 2$ & 0,891 & 0,400 & valid \\
\hline $\mathrm{Kmsl} 3$ & 0,902 & 0,400 & valid \\
\hline $\mathrm{Kmsl} 4$ & 0,957 & 0,400 & valid \\
\hline $\mathrm{Kmsl} 5$ & 0,802 & 0,400 & valid \\
\hline
\end{tabular}

Tabel 7

Uji Validitas Independensi Auditor

\begin{tabular}{|l|l|l|l|}
\hline Indikator & Pearson Corelation & Kriteria & Simpulan \\
\hline Ind 1 & 0,690 & 0,400 & valid \\
\hline Ind2 & 0,528 & 0,400 & valid \\
\hline Ind3 & 0,640 & 0,400 & valid \\
\hline Ind 4 & 0,785 & 0,400 & Valid \\
\hline Ind5 & 0,737 & 0,400 & valid \\
\hline
\end{tabular}


Tabel 8

Uji Reliabilitas

\begin{tabular}{|l|l|l|l|}
\hline Variabel & Cronbach Alpha & Kriteria & Simpulan \\
\hline Kualitas audit & 0,9058 & 0,600 & Reliabel \\
\hline Kompetensi & 0,8532 & 0,600 & Reliabel \\
\hline Komunikasi & 0,9192 & 0,600 & Reliabel \\
\hline Indpendensi & 0,8489 & 0,600 & Reliabel \\
\hline
\end{tabular}

Sebelum data dianalisis lebih lanjut menggunakan analisis regresi berganda, terlebih dahulu akan diuji normalitas, uji heteroskedastisitas, dan uji multikolinearitas. Evaluasi ini dimaksudkan untuk mengetahui apakah model regresi berganda sebagai alat analisis telah memenuhi beberapa asumsi klasik.

Uji normalitas dilakukan untuk mengetahui apakah data berdistribusi normal atau tidak. Model regresi yang baik adalah memiliki distribusi data normal atau mendekati normal. Pengujian normalitas menggunakan uji Kolmogorov-Smirnov, grafik histogram, dan kurva penyebaran PPlot (Elfarini, 2007: 63). Uji normalitas bertujuan untuk menguji apakah dalam model regresi variabel pengganggu atau residual mempunyai distribusi normal. Hasil pengujian normalitas menunjukkan bahwa sebaran data berdistribusi normal. Grafik normal plot menunjukkan bahwa titik-titik data berada disekitar garis diagonal serta penyebarannya mengikuti arah garis diagonal. Di samping itu, pada uji Kolmogorov-Smirnov, tampak pada hasil output SPSS menunjukkan bahwa besarnya nilai Kolmogorov-Smirnov adalah 1.088 dan tidak signifikan. Hal ini mengandung makna bahwa data terdistribusi normal.

Selanjutnya, heteroskedastisitas muncul apabila kesalahan atau residu dari model yang diamati tidak memiliki variansi yang konstan dari satu observasi ke observasi lainnya (Priadana, 2009: 193). Model regresi yang baik adalah yang homoskedastisitas atau tidak mengandung heteroskedastisitas (Elfarini, 2007: 63). Deteksi ada atau tidaknya heteroskedastisitas, bisa dilakukan dengan metoda grafik, yaitu melihat grafik plot antara nilai prediksi variabel dependen yaitu ZPRED dengan residualnya SRESID. Deteksi ada tidaknya heteroskedastisitas dapat dilakukan dengan melihat ada tidaknya pola tertentu pada grafik scatterplot antara SRESID dan ZPRED dimana sumbu $X$ adalah $\hat{Y}$ ( $Y$ yang telah diprediksi ZPRED) dan sumbu $Y$ adalah residu atau SRESID $(\hat{Y}-Y)$ yang telah distandarisasi. Pada gambar scatterplot sebaran data tampak bahwa tidak ada pola yang jelas, titik-titik menyebar diatas dan dibawah angka nol pada sumbu Y secara acak, maka tidak terjadi heteroskedastisitas atau model baik karena menunjukkan homoskedastisitas.

Data penelitian perlu juga diuji dengan uji MUltikolinearitas. Multikolinearitas adalah adanya suatu hubungan linear yang sempurna (mendekati sempurna) antara beberapa atau semua variabel bebas (Priadana, 2009: 193). Gujarati dalam Priadana (2009: 194) mengatakan bila korelasi antara dua variabel bebas melebihi 0,8 maka multikolinearitas menjadi masalah yang serius.

Berdasarkan hasil output matrik korelasi, pair-wise korelasi antara PENGALAM dan KOMPETEN sebesar 0.212, korelasi antara PENGALAM dan INDEPEND sebesar 0.121, korelasi antara PENGALAM dan KOMUNIKA sebesar -0.181, korelasi antara PENGALAM dan EFEKTIF sebesar 0.228 , korelasi antara PENGALAM dan KOMPOSIS sebesar 0.236 , korelasi antara KOMPETEN dan INDEPEND sebesar 0.028, korelasi antara KOMPETEN dan KOMUNIKA sebesar -0.533, dan seterusnya. Tampak bahwa tidak ada pair-wise korelasi yang tinggi diatas $80 \%$, jadi dapat 
disimpulkan bahwa tidak terdapat multikolinearitas antar variabel independen. Di samping itu, berdasarkan nilai Tolerance dan VIF terlihat bahwa tidak ada nilai tolerance dibawah 0.10 (nilai Tolerance berkisar antara 0.459 sampai 0.843), begitu juga dengan nilai VIF tidak ada yang diatas 10 (nilai VIF berkisar antara 1.273 sampai 2.180) jadi dapat disimpulkan bahwa tidak ada multikolinearitas yang serius.

Tabel 9

Uji Multikolinearitas

\begin{tabular}{|c|c|c|c|c|c|c|c|c|}
\hline \multirow{2}{*}{\multicolumn{2}{|c|}{ Model }} & \multicolumn{2}{|c|}{$\begin{array}{l}\text { Unstandardized } \\
\text { Coefficients }\end{array}$} & \multirow{2}{*}{$\begin{array}{c}\text { Standardized } \\
\text { Coefficients } \\
\text { Beta }\end{array}$} & \multirow[b]{2}{*}{$t$} & \multirow[b]{2}{*}{ Sig. } & \multicolumn{2}{|c|}{ Collinearity Statistics } \\
\hline & & B & Std. Error & & & & Tolerance & VIF \\
\hline \multirow[t]{7}{*}{1} & (Constant) & 18.734 & 3.436 & & 5.453 & .000 & & \\
\hline & PENGALAMAN & -.057 & .059 & -.121 & -.967 & .337 & .843 & 1.186 \\
\hline & KOMPETEN & -.009 & .170 & -.008 & -.051 & .960 & .585 & 1.709 \\
\hline & INDEPEND & .071 & .107 & .085 & .660 & .511 & .785 & 1.273 \\
\hline & KOMUNIKA & .217 & .125 & .295 & 1.743 & .086 & .459 & 2.180 \\
\hline & EFEKTIF & 1.534 & .868 & .265 & 1.767 & .082 & .586 & 1.705 \\
\hline & KOMPOSIS & -.027 & .167 & -.021 & -.160 & .874 & .751 & 1.331 \\
\hline
\end{tabular}

a. Dependent Variable: KAUDIT

Uji autokorelasi bertujuan menguji apakah dalam suatu model regresi linear ada korelasi antar residual. Masalah ini bisa timbul karena residual tidak bebas dari satu observasi ke observasi lainnya. Untuk mendeteksi ada tidaknya autokorelasi bisa dilakukan uji Durbin-Watson (DW test).

Tabel 10

Uji Autokorelasi

\begin{tabular}{|l|r|r|r|r|r|}
\hline Model & \multicolumn{1}{|c|}{$R$} & R Square & $\begin{array}{c}\text { Adjusted R } \\
\text { Square }\end{array}$ & $\begin{array}{c}\text { Std. Error of } \\
\text { the Estimate }\end{array}$ & $\begin{array}{c}\text { Durbin- } \\
\text { Watson }\end{array}$ \\
\hline 1 & $.344 a$ & .118 & .039 & 2.484 & 1.864 \\
\hline
\end{tabular}

a. Predictors: (Constant), KOMPOSIS, INDEPEND, PENGALAMAN,

KOMUNIKA, EFEKTIF, KOMPETEN

b. Dependent Variable: KAUDIT

Berdasarkan nilai tabel Durbin-Watson dengan $\mathrm{K}=6$ dan $\mathrm{n}=74$ didapatkan $\mathrm{dL}=1.458, \mathrm{dU}=1.801$. Sementara nilai Durbin-Watson adalah 1.864 berada diatas dU=1.801, maka dapat disimpulkan bahwa tidak terjadi autokorelasi antar residu data. 


\section{PENGUJIAN HIPOTESIS}

Pengujian terhadap hipotesis dalam penelitian ini dilakukan dengan menggunakan regresi berganda. Di dalamnya tercakup uji statistik F dan uji statistik t. Uji statistik F pada dasarnya menunjukkan apakah semua variabel bebas yang dimasukkan dalam model mempunyai pengaruh secara bersama-sama terhadap variabel terikat (Priadana, 2009: 188). Uji statistik $\dagger$ pada dasarnya menunjukkan seberapa jauh pengaruh satu variabel penjelas secara individual dalam menerangkan variasi variabel terikat (Priadana, 2009: 187).

Hasil pengujian menunjukkan bahwa secara keseluruhan keenam variabel independen yang digunakan untuk memprediksi kualitas audit hanya mampu menjelaskan 11,8 \% variasi kualitas audit. Hal ini dapat dilihat melalui koefisien determinasi $\left(R^{2}\right)$ pada tabel berikut ini.

Tabel 11

Model Summary

\begin{tabular}{|c|c|c|c|c|}
\hline $\begin{array}{c}\text { Mode } \\
\text { l }\end{array}$ & $R$ & R Square & $\begin{array}{c}\text { Adjusted } \\
\text { R Square }\end{array}$ & $\begin{array}{c}\text { Std. Error of } \\
\text { the } \\
\text { Estimate }\end{array}$ \\
\hline 1 & .344 (a) & .118 & .039 & 2.484 \\
\hline
\end{tabular}

a Predictors: (Constant), KOMPOSIS, INDEPEND, PENGALAM, KOMUNIKA, EFEKTIF, KOMPETEN

Berdasar tabel uji ANOVA atau $F$ test diperoleh nilai $F$ hitung sebesar 1,496 dengan probabilitas 0.193. Oleh karena probabilitas jauh lebih besar dari alpha, maka dapat disimpulkan bahwa koefisien regresi Komposisi, independensi, pengalaman, komunikasi, efektivitas, dan kompetensi secara simultan tidak berpengaruh terhadap kualitas audit (KA).

Tabel 12

ANOVA

\begin{tabular}{|l|l|r|r|r|r|r|}
\hline Model & & $\begin{array}{c}\text { Sum of } \\
\text { Squares }\end{array}$ & df & \multicolumn{1}{c|}{$\begin{array}{l}\text { Mean } \\
\text { Square }\end{array}$} & \multicolumn{1}{c|}{ F } & \multicolumn{1}{c|}{ Sig. } \\
\hline 1 & Regressi & 55.418 & 6 & 9.236 & 1.496 & $.193(\mathrm{a})$ \\
& on & 67 & 6.173 & & \\
& Residual & 413.569 & 67 & & & \\
& Total & 468.986 & 73 & & & \\
\hline
\end{tabular}

a Predictors: (Constant), KOMPOSIS, INDEPEND, PENGALAM, KOMUNIKA, EFEKTIF, KOMPETEN

b Dependent Variable: KAUDIT

Selanjutnya berdasarkan uji parsial per variabel terhadap kualitas audit diperoleh hasil analisis sebagai berikut. 
Tabel 13

Pengujian Hipotesis

\begin{tabular}{|c|c|c|c|c|c|c|}
\hline \multirow[t]{2}{*}{ Model } & & \multicolumn{2}{|c|}{$\begin{array}{l}\text { Unstandardized } \\
\text { Coefficients }\end{array}$} & \multirow{2}{*}{$\begin{array}{c}\text { Standardize } \\
\text { d } \\
\text { Coefficients } \\
\text { Beta } \\
\end{array}$} & \multirow[t]{2}{*}{$t$} & \multirow[t]{2}{*}{ Sig. } \\
\hline & & B & Std. Error & & & \\
\hline \multirow[t]{7}{*}{1} & (Constant) & 18.734 & 3.436 & & 5.453 & .000 \\
\hline & $\begin{array}{l}\text { PENGALA } \\
M\end{array}$ & -.057 & .059 & -.121 & -.967 & .337 \\
\hline & KOMPETEN & -.009 & .170 & -.008 & -.051 & .960 \\
\hline & INDEPEND & .071 & .107 & .085 & .660 & .511 \\
\hline & KOMUNIKA & .217 & .125 & .295 & 1.743 & .086 \\
\hline & EFEKTIF & 1.534 & .868 & .265 & 1.767 & .082 \\
\hline & KOMPOSIS & -.027 & .167 & -.021 & -.160 & .874 \\
\hline
\end{tabular}

a Dependent Variable: KAUDIT

Hasil analisis menunjukkan bahwa dari enam variabel yang diduga memiliki pengaruh terhadap kualitas audit hanya dua variabel yaitu komunikasi dan efektivitas penggunaan waktu yang berpengaruh terhadap kualitas audit yang ditunjukkan dengan tingkat signifikansi yang signifikan pada alpha $10 \%$. Dengan demikian hanya hipotesis 5 dan 6 yang didukung. Sementara hipotesis 1, 2, 3, dan 4 gagal untuk menolak hipotesis nol.

\section{SIMPULAN}

Hasil analisis di atas telah menunjukkan bahwa hanya komunikasi dan efektivitas penggunaan waktu yang signifikan. Dalam konteks dinamika tim audit masalah komunikasi dan penggunaan waktu adalah hal yang penting yang menunjang terwujudnya kualitas audit yang baik. Hasil analisis ini tidak mendukung hipotesis independensi, pengalaman, dan kompetensi karena variabel-variabel ini diduga lebih mencerminkan individu akuntan publik dibanding variabel kelompok. Mungkin secara individual variabel ini mungkin saja memiliki pengaruh. Namun secara kelompok variabel ini tidak berpengaruh. Di samping variabel-variabel tersebut, variabel komposisi tim audit yang awalnya diduga memiliki pengaruh ternyata tidak didukung. Hal ini mungkin mengindikasikan bahwa komposisi tidak terlalu penting, yang penting adalah bagaimana komunikasi dan efektivitas penggunaan waktu audit dalam dinamika kelompok terjalin dengan baik. Dalam kondisi ekstrim, mungkin tanpa komposisi yang lengkap sekalipun, tim audit akan dapat menunjukkan kualitas audit yang baik, jika di dalamnya ada komunikasi yang baik.

\section{KETERBATASAN PENELITIAN}

Penelitian ini memiliki keterbatasan dalam hal pengumpulan data. Berhubung data primer yang digunakan, maka keterbatasan mendasar adalah bahwa peneliti tidak dapat mendampingi para responden dalam mengisi kuesioner sehingga tidak dapat memastikan apakah memang benar-benar yang mengisi kuesioner penelitian adalah para responden yang dimaksud. Walaupun demikian, dalam kuesioner yang disebar, peneliti telah menaruh pertanyaan control untuk meminimalkan terjadinya kesalahan responden. 


\section{REFERENSI}

Arens. 2004. Auditing and Assurance Service. Salemba Empat, Jakarta.

Badan Standardisasi Nasional. 2005. Panduan Audit Sistem Manajemen Mutu dan/atau Lingkungan. SNI 19-19011-2005. www.kp2ma.vajy.ac.id.

Boynton, Wi. C., R. N. Johnson, dan W. G. Kell. 2003. Modern Auditing. Edisi Ketujuh, Jilid I, Erlangga, Jakarta.

Chaney, P. K., D. C. Jeter, dan P. E. Shaw. 2003. The Impact on The Market For Audit Services of Aggressive Competition by Auditors. Journal of Accounting and Public Policy Vol. 22, P 487-516

De Angelo, L. E, 1981, Auditor Size and Audit Quality. Journal of Accounting \& Economics, Vol. 3.

Elfarini, E. C. 2007. Pengaruh Kompetensi dan Independensi Auditor terhadap Kualitas Audit (Studi Empiris pada Kantor Akuntan Publik di Jawa Tengah). Skripsi Fakultas Ekonomi Universitas Negeri Semarang- Tidak dipublikasikan.

Fakhani, A. 2004. Analisis Atas Faktor-faktor Penunjang Kinerja Tim Audit dan Efektivitas Pencapaian Tujuan Audit (Studi pada Kantor Perwakilan Khusus dan Perwakilan I-VI BPKRI). Karya Akhir Program Studi Magister Akuntansi Fakultas Ekonomi Universitas Indonesia.

Febrianto, R.. 2009. Proksi Kualitas Auditor. http.//ideriset.blogspot.com.

Guy, D. M., C. W. Alderman, dan A. J. Winters. 2002. Auditing. Edisi kelima, Jilid I, Erlangga, Jakarta.

Hardies, K, D. Breesch, dan J. Branson. 2009. Are Female Auditors Still Women? Analyzing the sex differences affecting audit quality. Submitted Manuscript Faculty of Economic, Social and Political Sciences, and Solvay Business School, Free University of Brussels, Belgium

Ho, J. L., dan R. G. May. 1993. Auditor's Causal Probability Judgment in Analitical Prosedure for Auditing Planning. Behavioral Research in Accounting, Vol. 5 : 78-100.

Ishak, M. 2000. Analisis Faktor-Faktor Penentu Kualitas Audit Menurut Persepsi Klien. Tesis S2, (tidak dipublikasikan) Fakultas Ekonomi Universitas Gajah Mada, Yogyakarta.

Johnson, E. N. 1994. Auditor Memory for Audit Evidence : Effect of Group Assintance, Time Delay, and Memory Task, Auditing. A Journal for Pratice and Theory, (Spring), Vol. 13, No. $1: 36-56$.

Keen, T. R., dan C. N. keen. 1998. Conducting A Team Audit. American Society for Training and Development, Inc.

Ketchend, A. A., dan J. R. Strawser. 1998. The Existence of Multiple Measure of Organizational Commitment and Experience-Related Differences in a Public Acoounting Setting. Behavioral Research in Accounting, Vol. 10 : 109-137.

Libby, R., dan K. T. Trotman. 1993. The Review Process As A Control for Differential Recal of Evidence in Auditor Judgment. Accounting Organization and Society, Vol. 18, No. 6.

Mauts, R. K., dan H. A. Sharaf. 1961. The Philosophy of Auditing. American Accounting Association, Saratosa.

Muhammad, R. 2005. Pengaruh Struktur Organisasi terhadap Komunikasi dalam Tim Audit. Jurnal Akuntansi dan Auditing Indonesia (JAAI), Vol. 9 No. 2, Desember 2005: 127 - 142.

Nizarul M., Hapsari T., dan Purwanti L. 2007. Pengaruh Kompetensi dan Independensi terhadap Kualitas Audit dengan Etika Auditor sebagai Variabel Moderasi. Simposium Nasional Akuntansi X. Makasar: 26-28 Juli 2007.

Noviyanty, R., dan Indra Wijaya Kusuma. 2001. Analisis Faktor-Faktor yang Mempengaruhi Independensi Penampilan Akuntan Publik. Jurnal Akuntansi dan auditing Indonesia, Vol. 5, No. 1, Juni, hal. 1-16.

Nurchasanah, R., dan W. Rahmanti. 1999. Analisis Faktor-Faktor Penentu Kualitas Audit. Jurnal Akuntansi dan Manajemen. Fakultas Ekonomi Universitas Gajah Mada. Hal.47-60.

Prasetyo, T. A., dan R. Bramantyo. 2007. Teknik Komunikasi Audit. http://pusdiklatwas.bpkp.go.id. 
Yefta Andi Kus Nugroho

Dyah Ekasari Sekar Jatiningsih

Priadana, H., M. Sidik, dan Saludin Muis. 2009. Metodologi Penelitian Ekonomi dan Bisnis. Graha Ilmu, Yogyakarta.

Sar'i, M. 2010. Pengaruh Gaya Kepemimpinan dan Kultur Organisasi terhadap Komunikasi dalam Tim Audit. http://www.akuntansiku.com.

Tubbs, R. M. 1992. The Effect of Experience on The Auditors Organization and Amount of Knowledge. The Acoounting Review (October), Vol. 67, No. 4.

Watkins, Hillison, dan Morecroft. 2004. (http://ideriset.blogspot.com).

Widagdo, R., S. Lesmana, dan S. A. Irwandi. 2002. Analisis Pengaruh Atribut Kualitas Audit Terhadap Kepuasan Klien. Simposium Nasional Akuntansi (SNA), Vol. 5 : 560-574.

Wooten, T. C. 2003. Research About Audit Quality. The CPA Journal, Jan 2003: 48-51. 